\title{
Assessment of the Physico-Chemical Pollution of a Water Body in a Perspective of Integrated Water Resource Management: Case Study of Nokoué Lake
}

\author{
Josué Zandagba ${ }^{*}$, Firmin M. Adandedji², Daouda Mama², Amédée Chabi ${ }^{1}$, Abel Afouda ${ }^{3}$ \\ ${ }^{1}$ International Chair in Mathematical Physics and Applications (ICMPA), Cotonou, Benin \\ ${ }^{2}$ Laboratoire d'Hydrologie Appliquée (LHA), Institut National de l'Eau, Abomey-calavi, Benin \\ ${ }^{3}$ West African Science Service Center on Climate Change and Adapted Land Use, \\ Institut National de l'Eau, Abomey-calavi, Benin \\ Email: ${ }^{2}$ josua@yahoo.fr
}

Received 18 February 2016; accepted 15 April 2016; published 18 April 2016

Copyright (C 2016 by authors and Scientific Research Publishing Inc.

This work is licensed under the Creative Commons Attribution International License (CC BY). http://creativecommons.org/licenses/by/4.0/

\section{(c) (i) Open Access}

\begin{abstract}
Nokoué Lake is the most important surface of brackish waters of Benin and one of the biggest West African lagoons, in point of view of its surface (about $150 \mathrm{~km}^{2}$ ), its productivity and exploitation. The aim of this study is to monitor the temporal and spatial variation of physico-chemical parameters of Nokoué lake water for its sustainable management. A total of twenty (20) points of sampling have been followed during a period of one year. The results of the monitoring reveal low dissolved oxygen and high concentration in phosphorus and chlorophyll a, sign of eutrophication. In addition, nutrient concentrations (nitrites, phosphates, nitrates) responsible for the phenomenon compared to water quality assessment grid of the Organisation for Economic Co-operation and Development, (OECD) used to classify the waters in the range of hyper-eutrophic waters characterized by the proliferation of aquatic plants. So some measures have been proposed to remediate to this pollution in order to an integrated management.
\end{abstract}

\section{Keywords}

Water, Eutrophication, Nutrients, Nokoué Lake, Pollution

\footnotetext{
${ }^{*}$ Corresponding author.
}

How to cite this paper: Zandagba, J., Adandedji, F.M., Mama, D., Chabi, A. and Afouda, A. (2016) Assessment of the PhysicoChemical Pollution of a Water Body in a Perspective of Integrated Water Resource Management: Case Study of Nokoué Lake. Journal of Environmental Protection, 7, 656-669. http://dx.doi.org/10.4236/jep.2016.75059 


\section{Introduction}

Human societies have grown considerably since the second half of the nineteenth century, causing degradation, increasing of the quality of our environment from year to year [1].

Water resources are a particularly sensitive environment to human pressure mainly because it is through them that will carry out the collection and transfer of polluting substances or compounds in the environment. The quality of surface waters is testified, both coastal and inland, which have been greatly deteriorated in recent decades due to human activities such as agriculture, changes in land uses, waterproofing of the surfaces that is at the origin of the more important runoff and more concentrated in polluants, discharges of untreated wastewater into receiving waters and in difficult part access, the climate change that influences the temperature and the chemical characteristics of water bodies [2].

This deterioration of the natural characteristics leads to eutrophication of water bodies with the consequence of, increasing algae and aquatic plants, the highest risk of occurrence of cyanobacteria (blue algae), siltation of lakes, loss the transparency of water, loss of biodiversity and loss of interest species for fishing [3].

The study of physical and chemical characteristics of water thus derives its interest that the modification of its parameters may disrupt the functions of the water body, including the biological potential of water and its uses.

Nokoué Lake, purpose of this study, located in West Africa, faces some aggressions consecutive to the human activities and became thus a receiving basin of solid waste, liquids and other products without any previous treatment. In addition, as part of traditional fisheries, significant amounts of branches are daily dumped by fishermen for building acadjas [4]. It results in some exponential proliferation of unicellular algae, which gives the water a green color, and floating macrophytes developing [5].

\section{Materials and Methods}

\subsection{Study Area}

Nokoué Lake is located in southern Benin, in West Africa, between $6^{\circ} 25^{\prime} \mathrm{N}$ and $2^{\circ} 366^{\prime} \mathrm{E}$ (Figure 1). It is located in the sub-equatorial area, and underwent two rainy seasons and two dry seasons of unequal durations. The annual

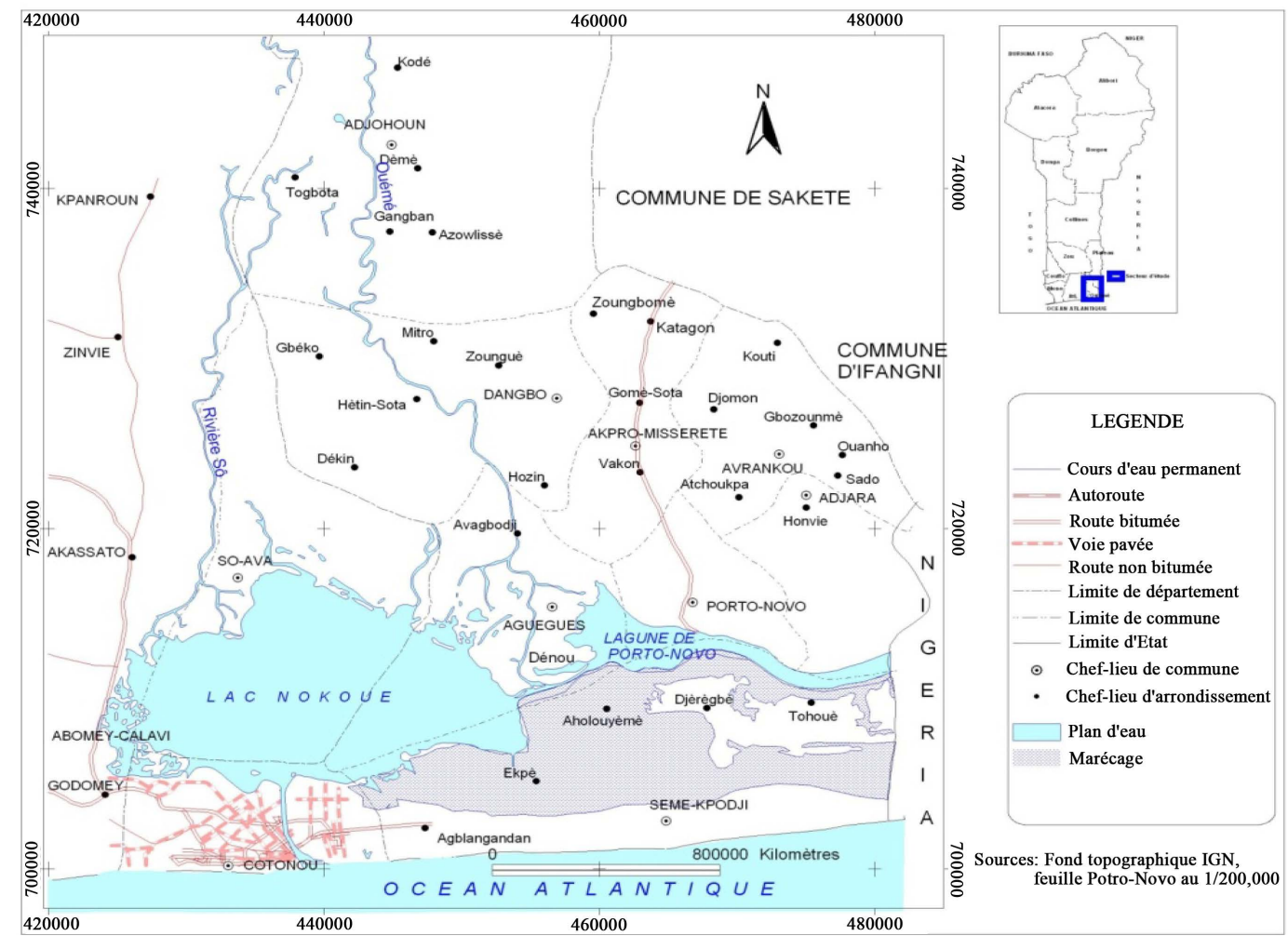

Figure 1. Location map of Nokoué Lake. 
rainfall is $1309 \mathrm{~mm}$, the average temperature of $27.7^{\circ} \mathrm{C}$ with the maxima up to $33^{\circ} \mathrm{C}$ and minimum at $23^{\circ} \mathrm{C}$. It covers an area of $150 \mathrm{~km}^{2}$ and is the largest lake of the country. This lake is connected to Porto-Novo lagoon at the East by the Totche Canal, at south by the Atlantic Ocean through the channel of Cotonou, and at north by the river Sô and Ouémé stream on which it depends [3]. This communication, together with the impact of natural flood of Sô and Ouémé stream, causes very significant seasonal variations of salinity which is parameter of that the variations during the year are the most important [4]. The lake could be considered ranging from shallow (0.4 to $3.4 \mathrm{~m})$.

\subsection{Sampling Sites}

In total, twenty sampling sites were followed up physico-chemical parameters during the four (04) seasons that undergoes the lake (Figure 2):

$\checkmark 03$ sites in the Sô River, tributary of Lake,

$\checkmark 01$ site at the entrance of the lake by Ouémé stream,

$\checkmark$ 01site at the entrance of the lake through river Djonou,

$\checkmark 01$ site at the entrance of the Lake by Totchè channel,

$\checkmark 02$ sites at the output by Cotonou channel,

$\checkmark 02$ sites in the center of the lake and the other in the lake in the light of the anthropic areas.

Two major reasons justify the choice of these sites:

- $\quad$ The geographical distribution(it is made to cover the entire river-lagoon system);

- The entrances, exits and areas where various human activities on the lake occur.

\subsection{Research Methods}

The methodology adopted was to make in situ measurements and laboratory analyzes of a few indicative pollution

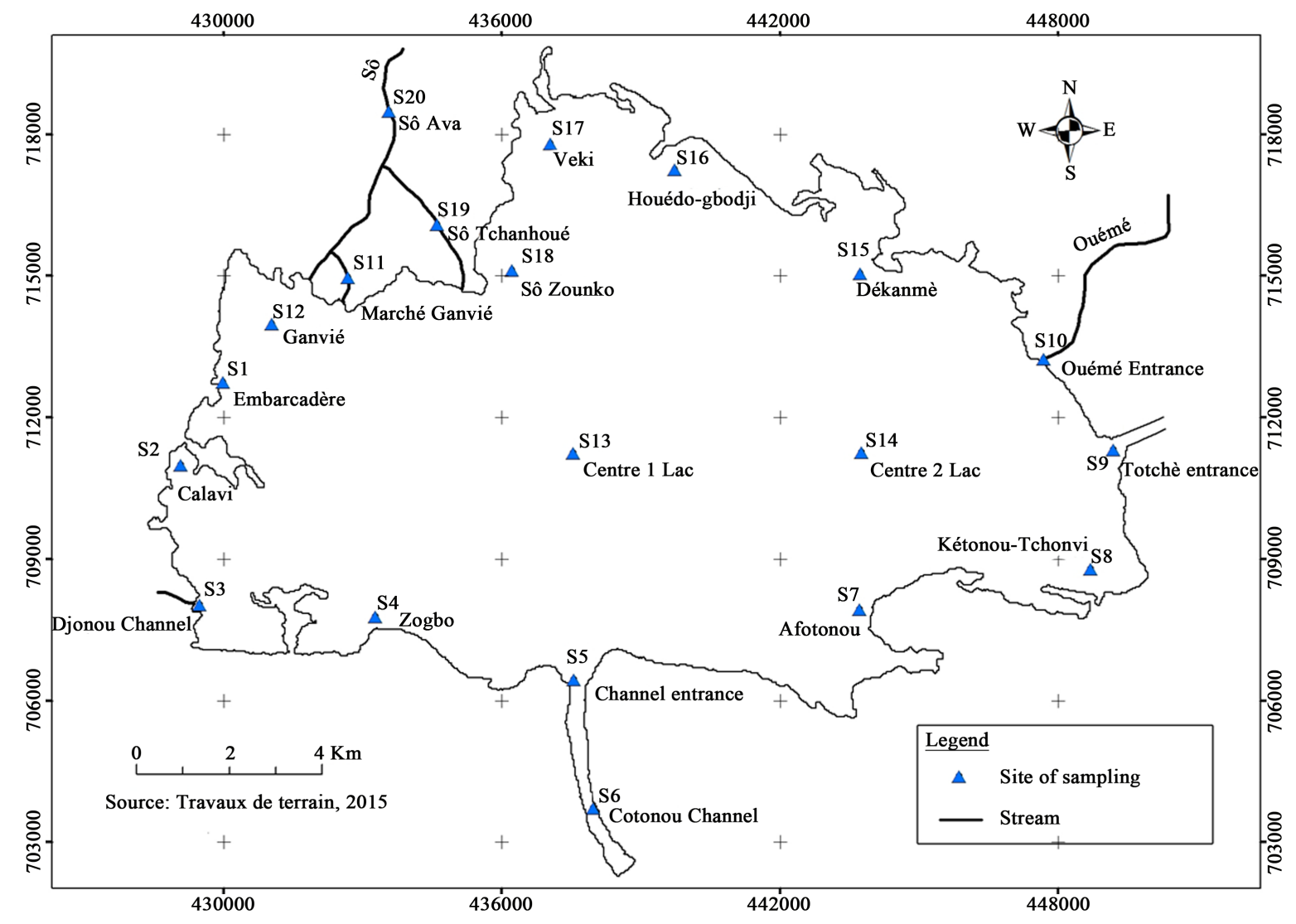

Figure 2. Location of the sampling sites. 
parameters. The water samples were taken and cover the following periods:

- February 2015 corresponding to the long dry season and low water period,

- April 2015 corresponding to the start of the rainy season,

- June 2015 corresponding to the rainy season,

- September, 2015 corresponding to the short rains and high water period (northern waters of descent to the south),

- November, 2015 corresponding to the long dry season and the period of low water (removal of flood waters). These water samples were taken in calm water in $5 \mathrm{~cm}$ surface with 1.5 liter bottles in plastic previously rinsed and dried, and then are kept cool in a cooler. Some parameters were measured in situ, others determined in the laboratory.

The measures carried out in-situ mainly concern:

- The location of sampling stations with a Garmin GPS72;

- Salinity, electrical conductivity, TDS and the temperature of the water with a conductivity meter (HACH);

- The $\mathrm{pH}$ with a $\mathrm{pH}$ meter (HACH);

- Dissolved oxygen with an oximeter WTW340i.

Different laboratory analysis methods were referenced to standard methods AFNOR (1997) (Table 1).

\section{Results and Discussion}

\subsection{Results}

\section{Physical parameters}

The temperature values vary between $26.9^{\circ} \mathrm{C}$ (June) and $33.5^{\circ} \mathrm{C}$ (April) with an average of $29.68^{\circ} \mathrm{C}$ (Figure 3). The biggest are obtained in April at S12 site and in November at S14 site, while the lowest was observed in June at the point S15.It was observed that at S4, S5, S6, S7, S13 and S14 sites, the waters are relatively cooler, because this points are directly subject to the influence of the tide, so benefitting regularly fresh water from the ocean. We must also notice low temperature values at the stations upstream, this is due to the contribution of So and Ouémé rivers.

Potential Hydrogen $(\mathrm{pH})$ of the lake water varies between 6.12 and 8.78 (November) (Figure 4). We find that the lowest and the highest value were respectively observed at S3 and S13 sites.

The average $\mathrm{pH}$ value on the whole lake is 7.6, the water can so be considered feebly basic. The analysis of the data indicates acidic pH values at site 3 in February, April, November, and at S11, S19 and S20 in June and November. Indeed, at these sites, humic acid, which comes from the decomposition of the dead macrophytes is the cause of lower value of $\mathrm{pH}$. However during September, period of high water, the $\mathrm{pH}$ is basic on entire lake. This could be explained by the rising waters with dilution effects for rain and inland waters acids. The $\mathrm{pH}$ of the water surface depends on the $\mathrm{CO}_{2}$ concentration. Algal photosynthesis consumes a lot of $\mathrm{CO}_{2}$ and thus causes a significant increase in water $\mathrm{pH}$.

Table 1. Laboratory analysis methods.

\begin{tabular}{|c|c|}
\hline Monitored parameters & Devices and methods \\
\hline pH, Température, dissolved oxygen & Direct measurement by multi-parameter pH/Oximeter WTW 340i \\
\hline Conductivity, salinity & Direct measurement by multi-parameter pH/Oximeter WTW 340i \\
\hline Suspended solids (SS), turbidity & Colorimeter HACH DR/890, Method 8025 \\
\hline Nitrite, Nitrate, & $\begin{array}{l}\text { Spectrophotometric method HACH LANGE DR } 2800 \\
\text { NitraVer }{ }^{\circledR} 5 \text { Nitrate Reagent for } 10 \mathrm{~mL} \text { sample, cat } 21061-69 \mathrm{Pk} / 100 \\
\text { NitriVer }{ }^{\circledR} 2 \text { Nitrite Reagent for } 10 \mathrm{~mL} \text { sample, cat } 21075-69 \mathrm{Pk} / 100 \\
\text { Colorimetric method (cadmium reduction method for Nitrates; diazotization } \\
\text { method nitristes, the Nessler Method for ammonium and nitrogen Kjeldahl) }\end{array}$ \\
\hline Biochemical oxygen demand after five days $\left(\mathrm{BOD}_{5}\right)$ & Oxytop respirometric method in a thermostatic chamber \\
\hline Chemical Oxygen Demand (COD) & AFNOR NF T90-101, Colorimètre, colorimeter, potassium dichromate method \\
\hline Chlorophyll a & Scor UNESCO method NF T 90-117 \\
\hline Total phosphorus and Ortho-Phosphates & Acid ascorbic Method \\
\hline
\end{tabular}




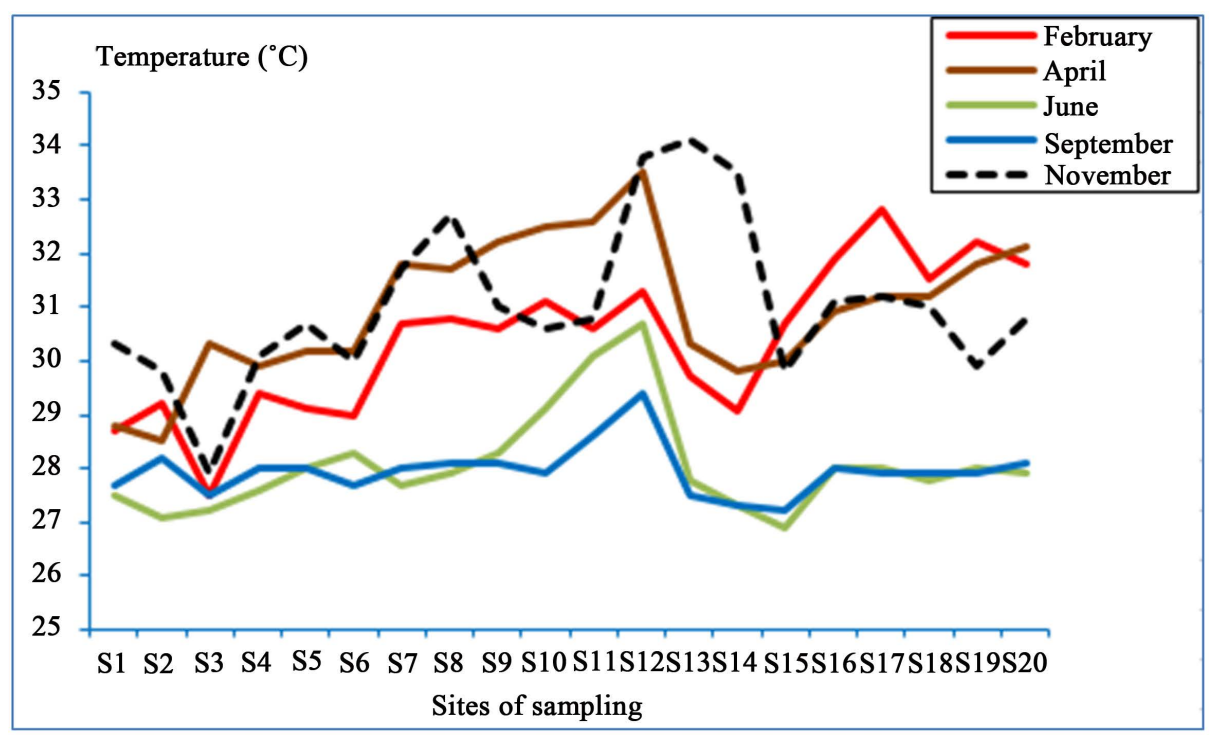

Figure 3. Variability of temperature.

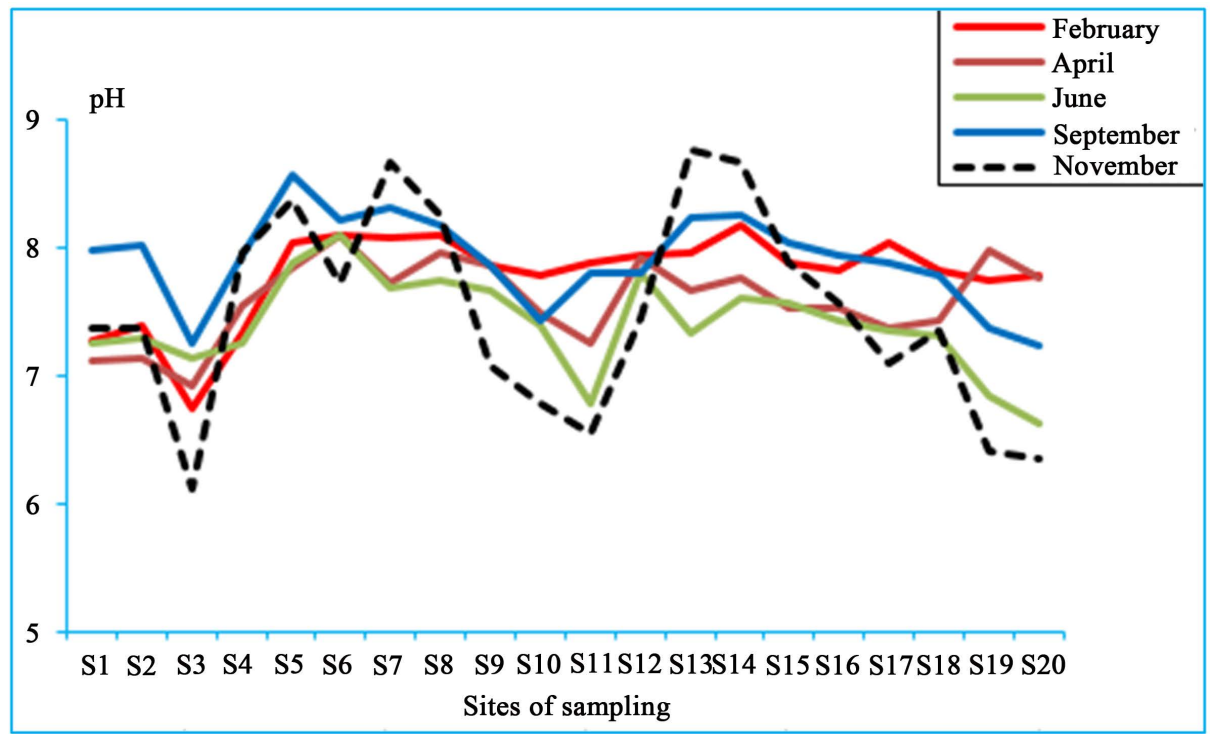

Figure 4. Variability of potential of hydrogen.

The conductivity and salinity variation on Figure 5 and Figure 6 reveal the highest values at the station S6 for all seasons. The lowest values were observed in November. The average value of the conductivity is 16.04 $\mathrm{mS} / \mathrm{cm}$ as against $8.57 \%$ of salinity.

Figure 5 and Figure 6 show a heterogeneous distribution of the conductivity and salinity depending on the season. There is a gradient of these parameters from upstream to downstream of the lake.

In fact, (S4, S5, S6 and S7) sites near Cotonou channel have higher salinity and conductivity values than those of the sites located in the Northern of the lake at upstream.

The results obtained show that dissolved oxygen values varying between $0.62 \mathrm{mg} / \mathrm{L}$ and $10.72 \mathrm{mg} / \mathrm{L}$ with a mean of $3.84 \mathrm{mg} / \mathrm{L}$ (Figure 7). The lowest values are observed in S11 and S3 sites in November and the highest level at S13, S15 in June and S14 in November.

The dissolved oxygen values superior to $7 \mathrm{mg} / \mathrm{L}$ (the Fish Water quality standards according to the 1978 guideline European communities advice) at stations S13 (middle of lake) in June and S4 and S15 stations in November. 


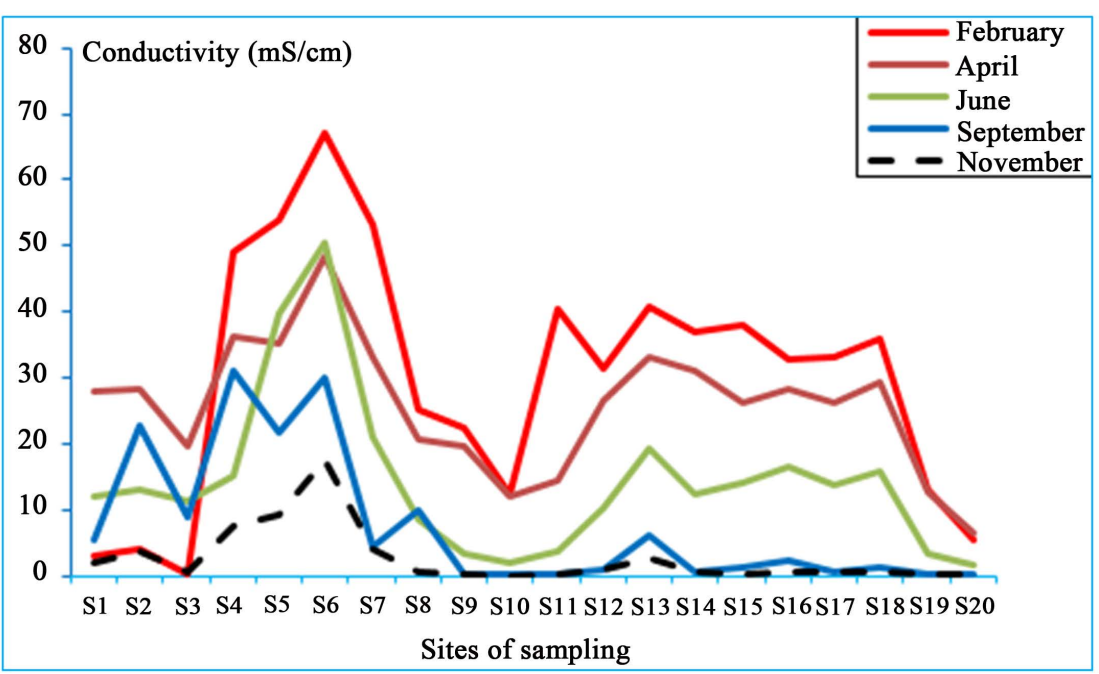

Figure 5. Variability of conductivity.

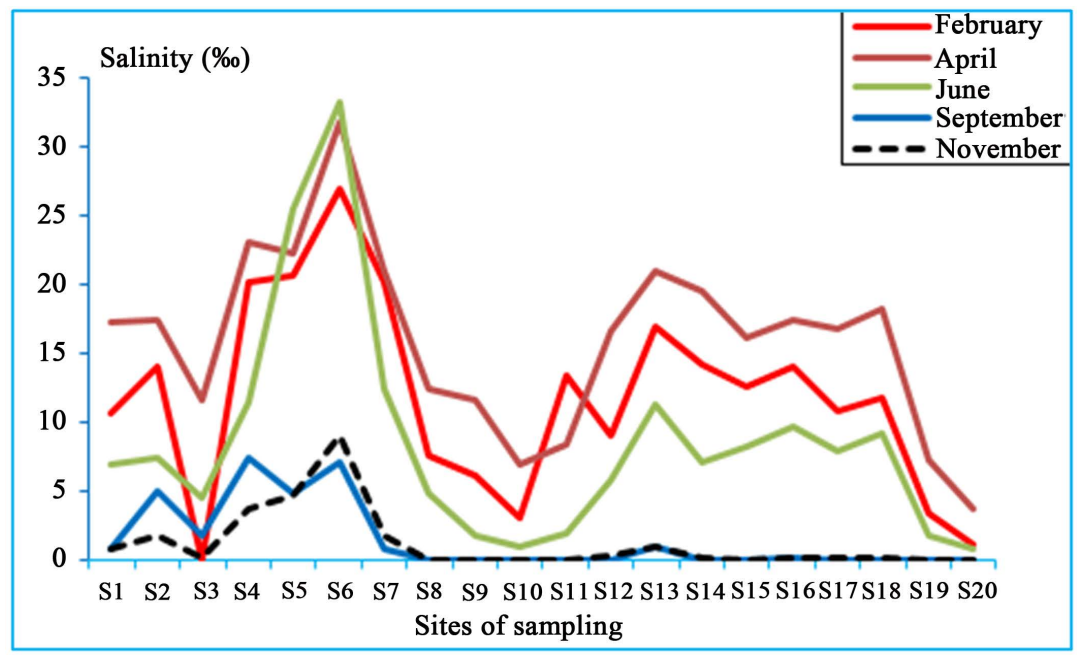

Figure 6. Variability of salinity.

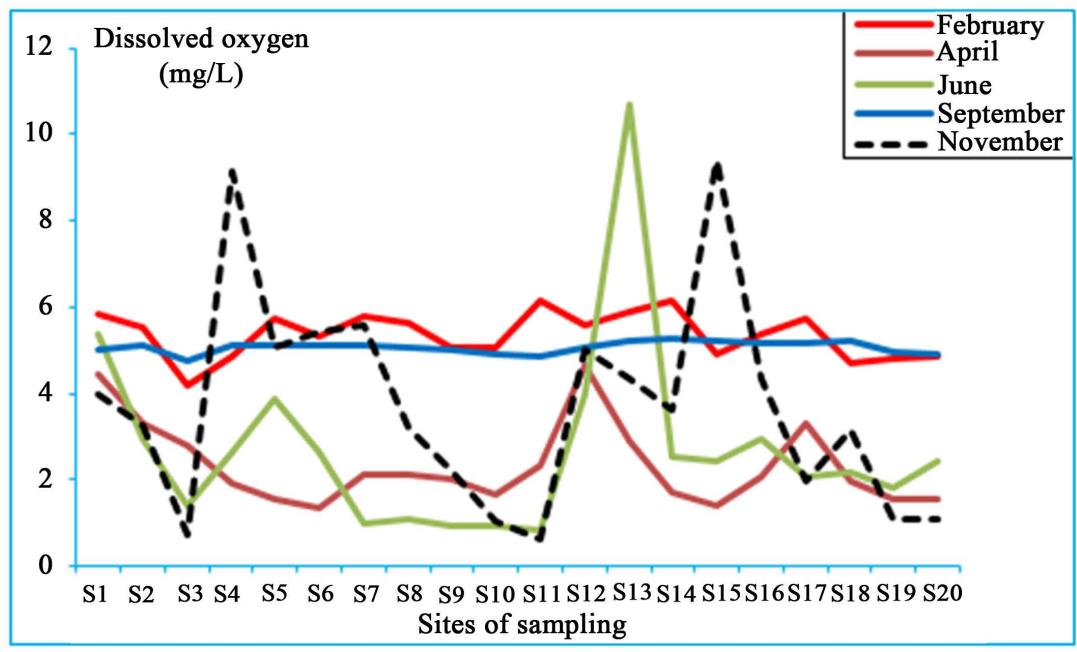

Figure 7. Variability of dissolved oxygen. 
From the mean values obtained perstation, it is noticeable that the stations S3, S10, S11, S19 and S20, respectively at the entrance of Djonou; entered the Ouémé; at Ganvié market; So Tchanhoué and So Ava, have values less than $3 \mathrm{mg} / \mathrm{L}$.

The highest turbidity values and suspended solids (SS) were observed in the months of June and September and especially on the websites S9, S10 and S14 (Figure 8 and Figure 9). By average values of turbidity and Suspended Solids observed, there are the strongest at the inputs of the lake from Totche and Ouémé due to the hydrological dynamics at these sites and at Abomey calavi pier because of the significant traffic noted in the area. This high turbidity could prevent penetration of light and oxygenation of the medium.

\section{Organic pollution}

The Biological Oxygen Demand (BOD) values vary between $1 \mathrm{mg} / \mathrm{L}$ and $29 \mathrm{mg} / \mathrm{L}$ (Figure 10), with the lowest observed in February and November at the site S3 and the highest in S2, S13 and S15 sites. The highest values are observed in February and April respectively corresponding to the dry season and the beginning of the rainy season.

The analysis of the graph of Figure 11 shows that the highest values of chemical oxygen demand (COD) are observed at S4 and S6 sites in April and September months (rainy season and high water period).

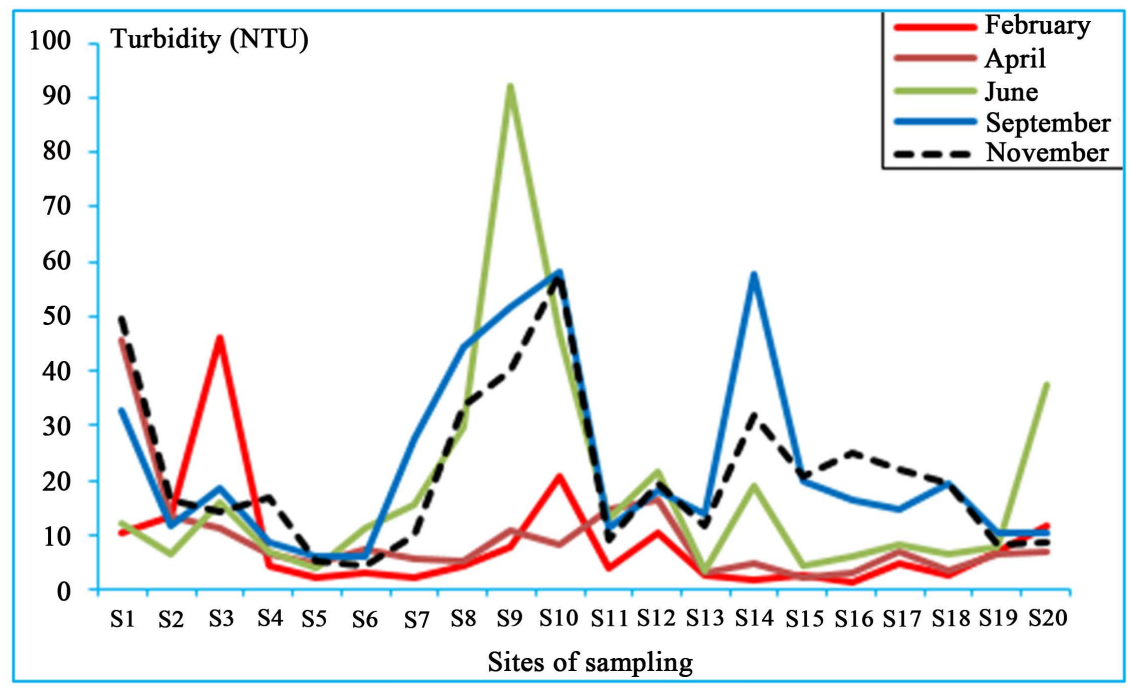

Figure 8. Variability of turbidity.

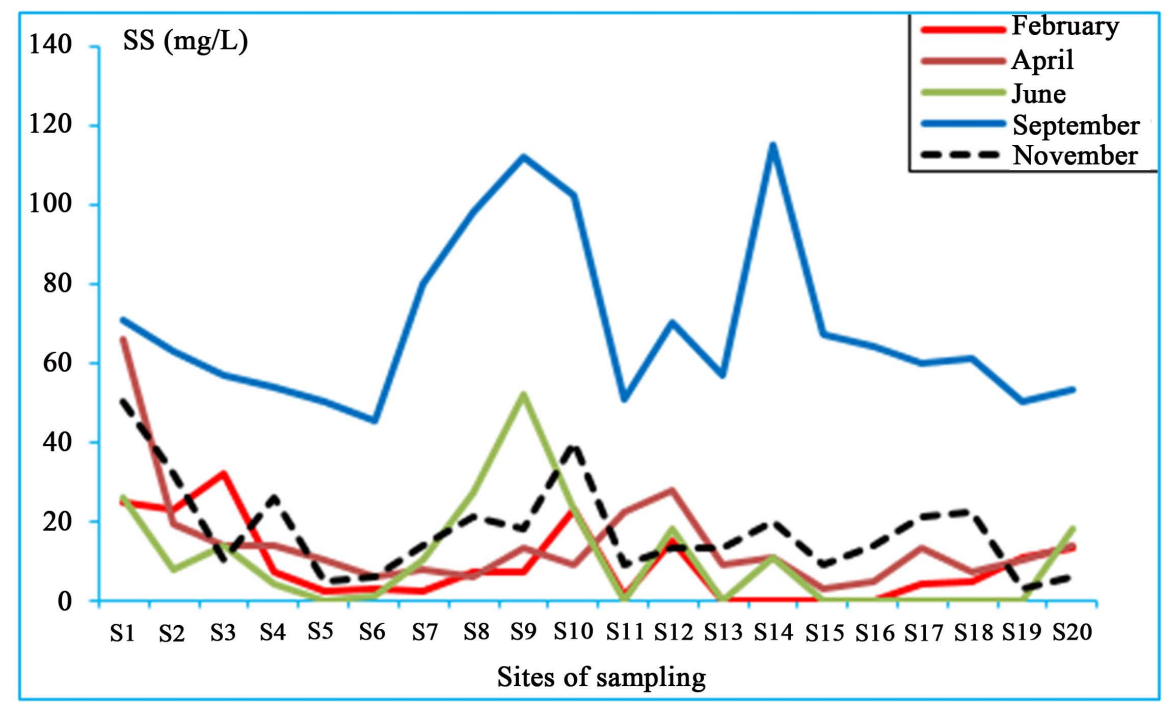

Figure 9. Variability of suspended solids. 


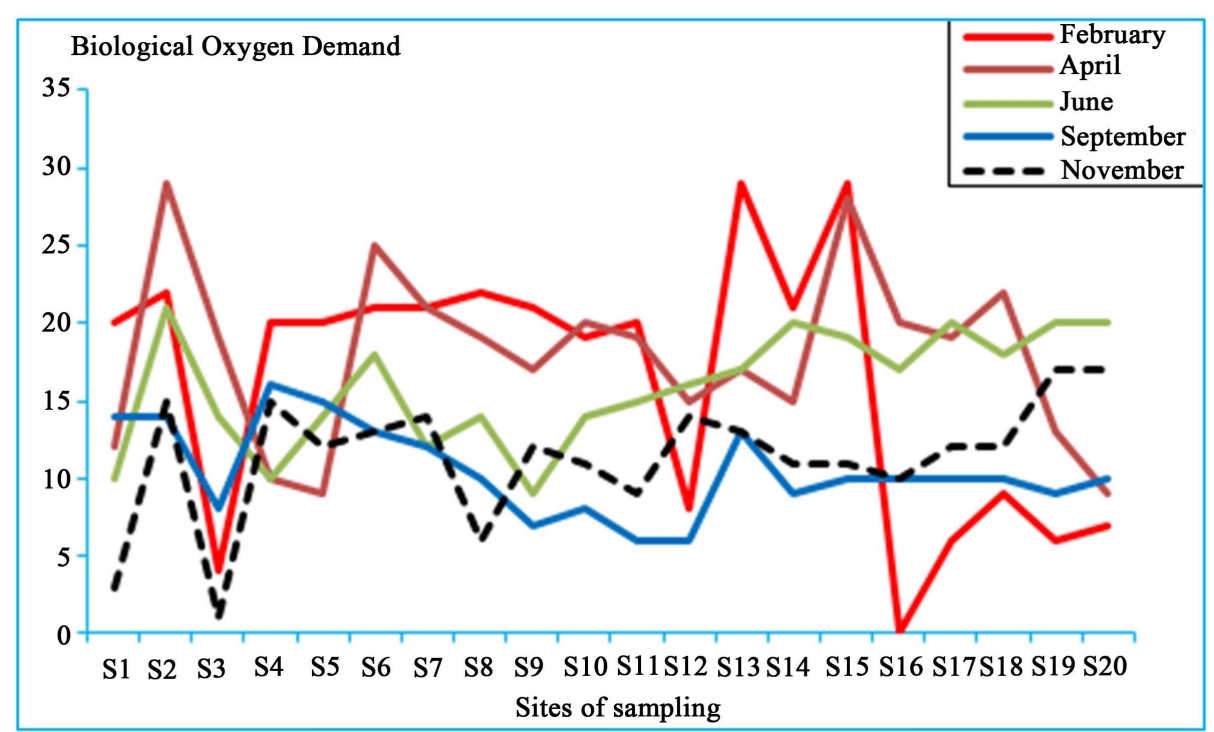

Figure 10. Variability of biological oxygen demand.

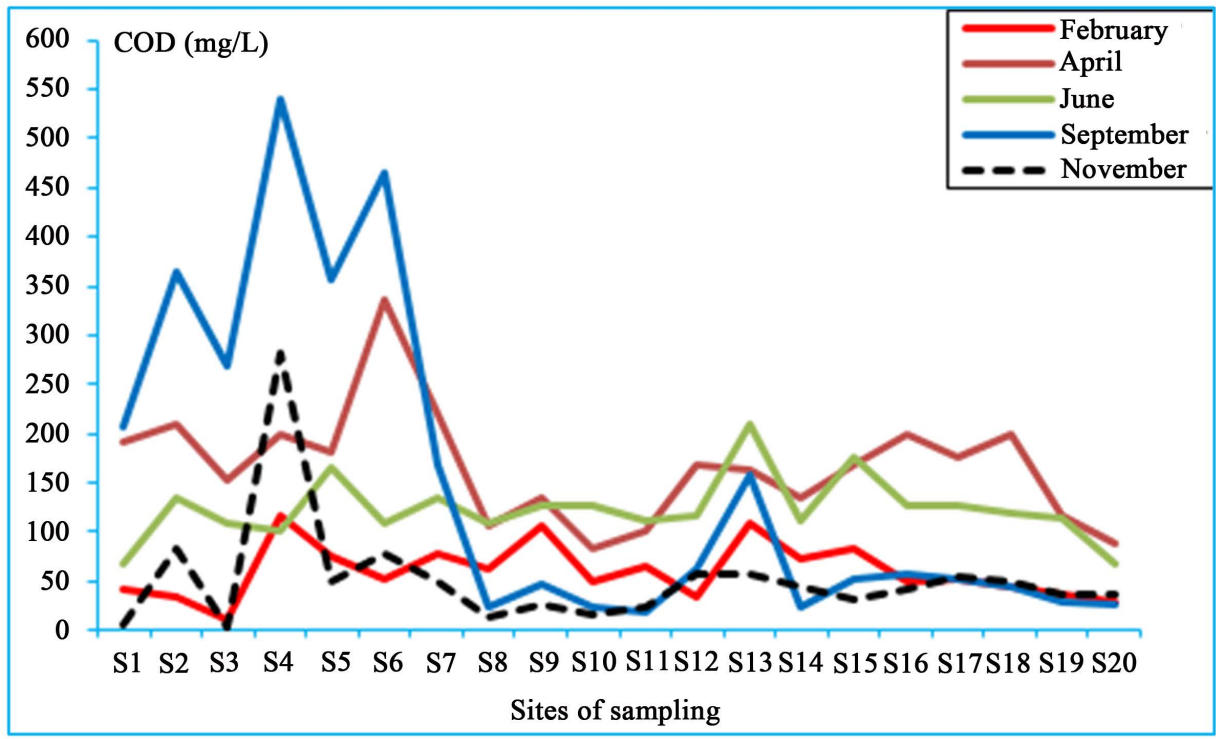

Figure 11. Variability of chemical oxygen demand.

The Chemical Oxygen Demand values range between 3.67 and $540.63 \mathrm{mg} / \mathrm{L}$. The largest were observed in areas near the houses, indicating the impact of sewage discharge.

\section{Nutrients (phosphorus and nitrogen compounds)}

The highest values of ortho-phosphate are observed at sites S6, S7, S8 and S10 in the month of April (Figure 12). The average concentration of ortho-phosphate of the lake water is $0.3 \mathrm{mg} / \mathrm{L}$.

Total phosphorus contents range between $0.21 \mathrm{mg} / \mathrm{L}$ and $24.58 \mathrm{mg} / \mathrm{L}$ (Figure 13). The highest values are observed in February including S4 and S15 sites and the weakest are those obtained in June (period of heavy rains). The mean average value on the lake is $3.4 \mathrm{mg} / \mathrm{L}$.

According to Figure 14 we see that the highest nitrite values are observed in the month of April corresponding to the start of the rainy season. These levels exceed the threshold value of $0.06 \mathrm{mg} / \mathrm{L}$ at the S6, S10, S18 and S19 sites. We also noted that the highest nitrate levels are found in the same month (Figure 15). As for the highest values they were observed in April at S1, S2 and S5 sites. S1 and S9 sites have the highest levels of ammonium particularly during the months of April and June (Figure 16). 


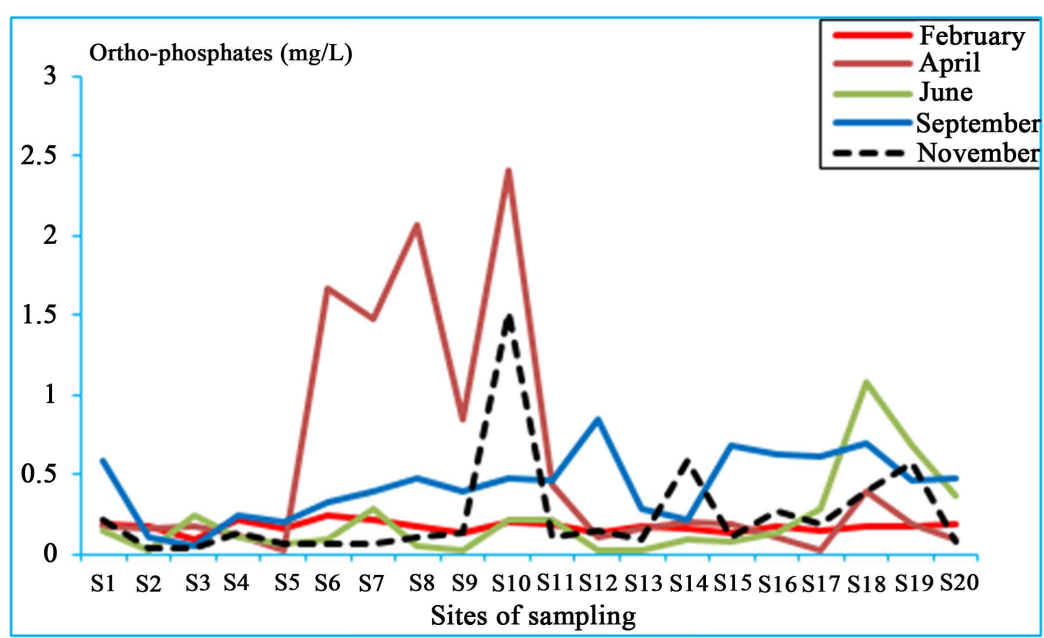

Figure 12. Variability of ortho-phosphate.

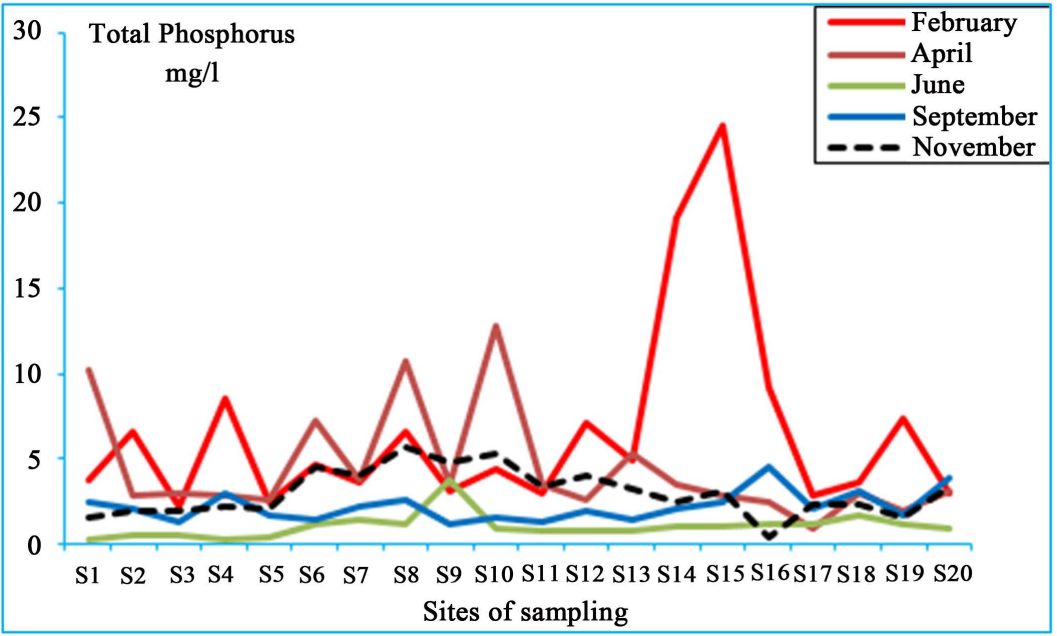

Figure 13. Variability of total phosphorus.

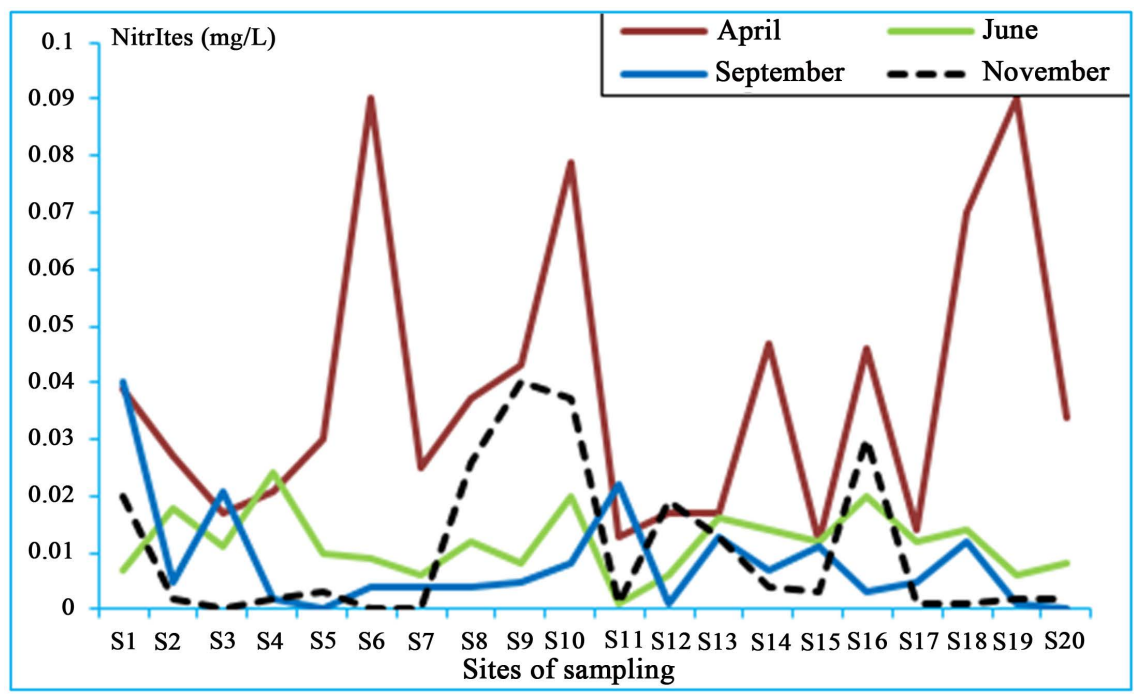

Figure 14. Variability of nitrite. 


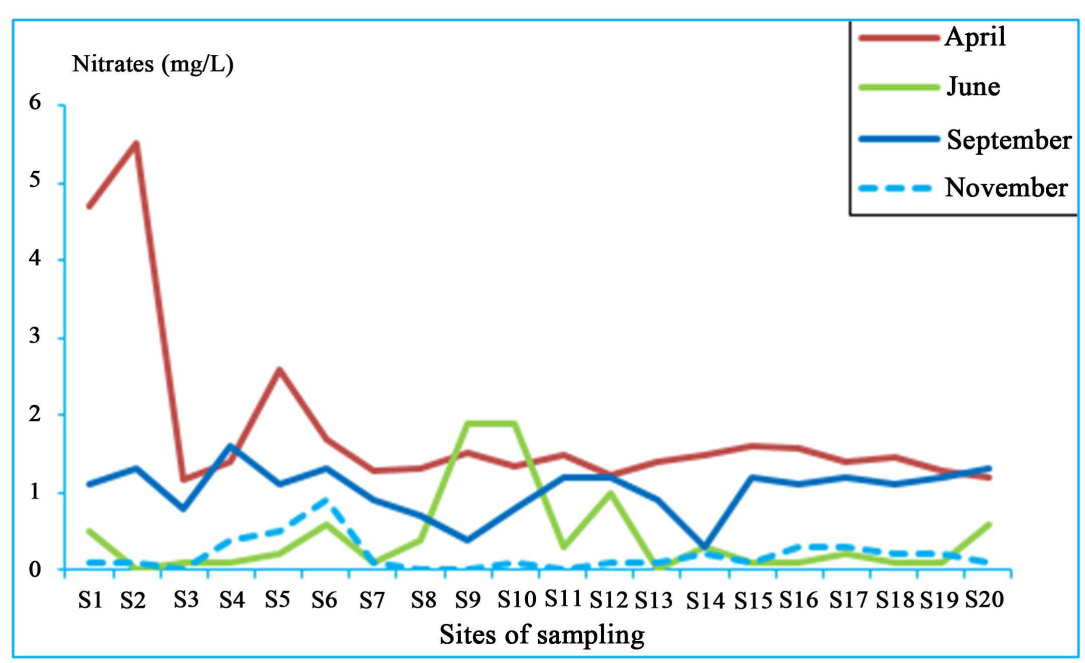

Figure 15. Variability of nitrate.

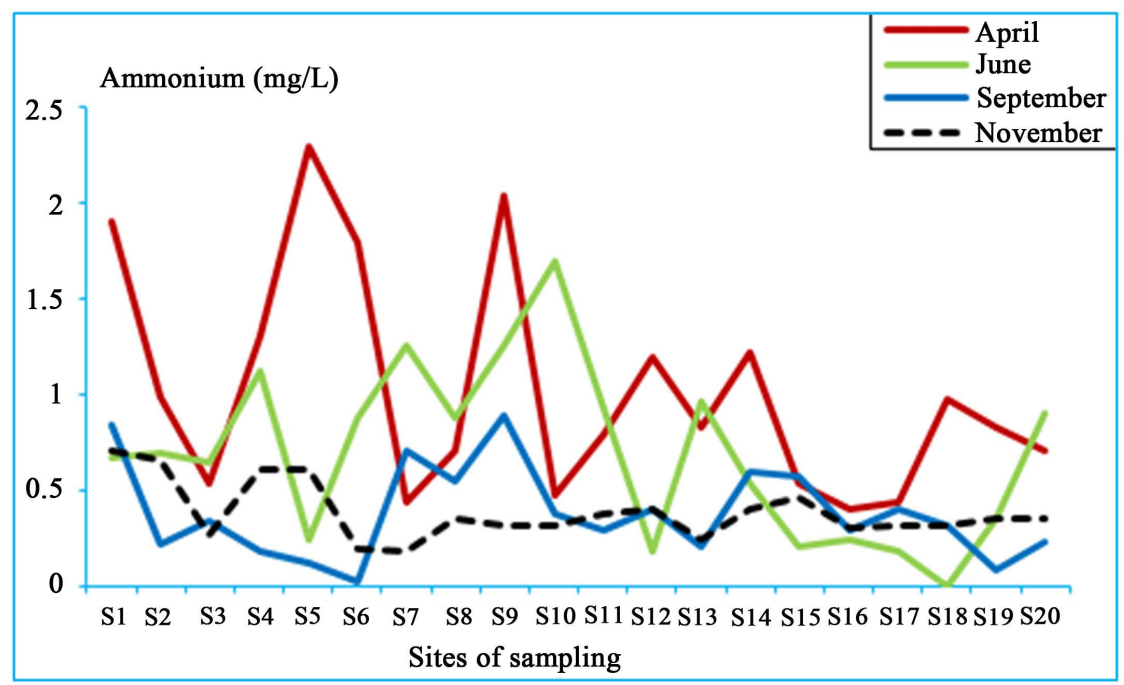

Figure 16. Variability of ammonium.

\section{Phytoplankton Biomass}

The observed values of chlorophyll a on Figure 17, vary between $1.16 \mu \mathrm{g} / \mathrm{L}$ (S5) in June and $3436.4 \mu \mathrm{g} / \mathrm{L}$ in February with an average of $307 \mu \mathrm{g} / \mathrm{L}$. The highest values were observed at the site S3, S13, S15 and S16 in the month of February (long dry season). These high levels indicate a production of algal biomass in the lake.

\subsection{Discussion}

The different parameters for assessing the water quality of Nokoué Lake are followed both temporal and spatial variabilities. Indeed, the observed temperature values are similar to those of [6] and [7] who showed that the temperatures between $24^{\circ} \mathrm{C}$ and $35^{\circ} \mathrm{C}$ are favorable for good growth of the fish species in aquaculture. The temperatures obtains are characteristic of tropical waters lagoons that oscillate between $25^{\circ} \mathrm{C}$ and $30^{\circ} \mathrm{C}$ on average [8]-[10]. The average temperature of $29.7^{\circ} \mathrm{C}$ is higher than the optimum temperature for growth of water hyacinths which is $27^{\circ} \mathrm{C}$. We can conclude that this parameter could contribute to the development of hyacinths in this system.

The hydrogen potential of water sampled at the monitored sites is between 6.5 and 9 which indicate a good quality water for aquaculture [11]. Beyond $\mathrm{pH}=9$, there are mortality for many species [12]. In view of this, all the values obtained for the $\mathrm{pH}$ is acceptable. These $\mathrm{pH}$ values between 6.5 and 8.5 reflect, according to water 


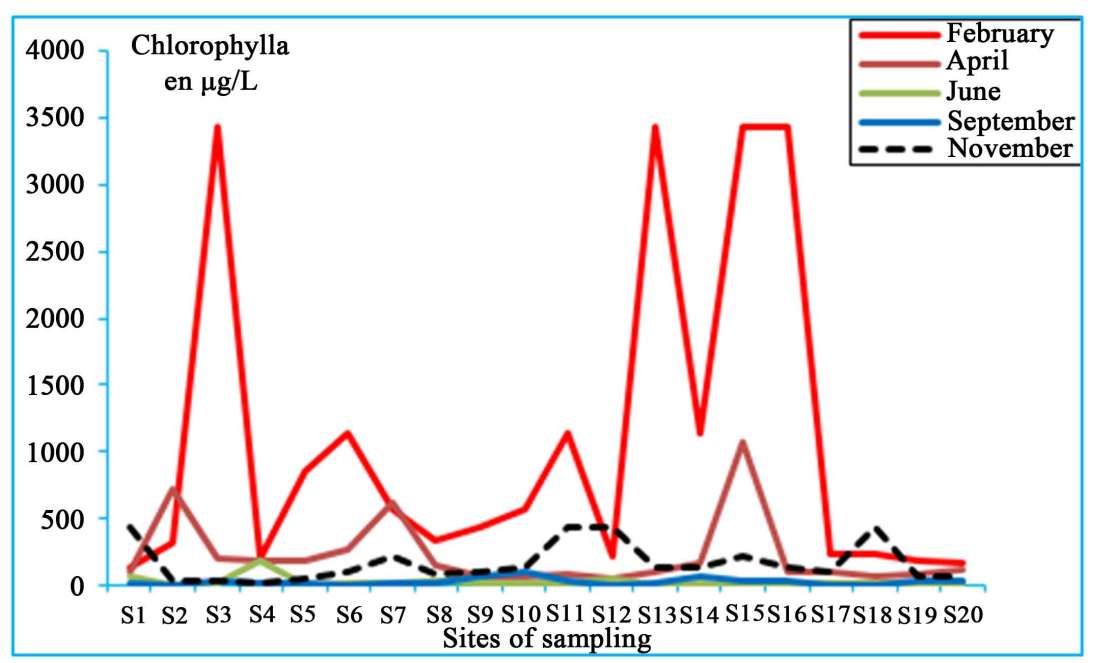

Figure 17. Variability of chlorophyll-a.

quality grid of Beaux (1998), good water quality of the lake. The values above 7 are generally related to eutrophication. This could be explained by the presence of phytoplankton, which, thanks to photosynthesis releases oxygen thereby increasing its concentration and consume $\mathrm{CO}_{2}$ causing the elevation of $\mathrm{pH}$ [13].

Nokoué Lake is in constant contact with the Atlantic Ocean which explains the fact that at the site S6 we observed the highest salinity and electric conductivity values linked to the presence of dissolved elements. This high salinity value observed in June (rainy season) is due to saline intrusion at high tide. The Nokoué Lake thus behaves like all tropical lake ecosystems characterized by freshening during flood season (due to contribution of rivers and streams) and high salinity in periods of low water. The mean registered value of salinity, $8.56 \%$, confirms the nature of the brackish waters of this lake. This could be explained by the fact that the influence of freshwater inflows from the stream, diffuse runoff and direct precipitation over the lake are less than the ocean flows.

These observed salinity values are significantly higher than those found by [14] and [15] who employed respectively on Moumoune and Marsili showed that salinity levels greater than $7 \mathrm{~g} / \mathrm{L}$ promotes the inhibition of growth of Eichhornia crassipes (water hyacinth) [16]. Zero salinity values are observed in the S3 sites (Djonou channel whose waters are sweet), S9, S10, S20, S11, S19 indicates that these points do not undergo or undergo weakly influences of ocean waters. Thus the spatial and temporal variations in salinity, depending on the relative importance of continental and oceanic flows, also condition the seasonal variation in water $\mathrm{pH}$. Thus, for high salinity periods correspond to those of basic water and strongly sequences influenced by continental weakly acidic water.

The lowest values of dissolved oxygen are observed in the month of April (early long rains) reflecting the strong chemical oxygen demand values observed for the same month at S4 and S6 sites. Dissolved oxygen is involved in respiration of aquatic organisms, oxidation and degradation of pollutants and contributes to the photosynthetic activity of plants and interaction with the atmosphere. The dissolved oxygen values observed for the April months are all less than $3 \mathrm{mg} / \mathrm{L}$ (except at S1, S2, S12 and S13), a threshold value of polluted water [17]. The low levels of dissolved oxygen recorded can be justified by the lack of continuous water flows, wastewater discharges of residents at upstream or at these points. The site S13 and S4 meanwhile has the highest rate of oxygenation, which would certainly due to the fact that it is located in the center of the lake and it is held there a permanent water renewal. The mean values obtained by season are above the limit value of $2 \mathrm{mg} / \mathrm{L}$ below which fish mortality is common [18]. These organisms are not at risk because of reduced dissolved oxygen concentrations that cause the lethal or sublethal effects (physiological and behavioral) in various organisms, in particular the fishes. The mean dissolved oxygen value is $3.8 \mathrm{mg} / \mathrm{L}$. This value between $3 \mathrm{mg} / \mathrm{L}$ and $6 \mathrm{mg} / \mathrm{L}$ allow us to classify the water as bad quality [19].

The low levels dissolved oxygen are related to high turbidity and suspended solids values that are highly correlated $(r=0.806)$ (Table 2). The highest values observed in June and November are probably related to the decomposition of macrophytes in the lake [3]. 
Table 2. Correlation matrix of the various parameters of Nokoué Lake.

\begin{tabular}{|c|c|c|c|c|c|c|c|c|c|c|c|c|c|c|c|c|}
\hline & $\mathbf{T}^{\circ} \mathrm{C}$ & sal & TDS & Cond & DO & pH & Turb & SS & BOD & COD & Chl. a & PT & O-P & $\mathrm{NO}_{2}^{-}$ & $\mathrm{NO}_{3}^{2-}$ & $\mathrm{NH}_{4}^{+}$ \\
\hline $\mathbf{T}^{\circ} \mathbf{C}$ & 1.00 & -0.04 & 0.25 & 0.08 & -0.08 & 0.18 & -0.26 & 0.5 & 0.04 & -0.21 & 0.16 & 0.28 & 0.18 & 0.53 & 0.28 & 0.3 \\
\hline Sal & & 1.00 & -0.20 & 0.88 & -0.01 & 0.21 & 0.41 & -0.40 & 0.27 & 0.27 & 0.12 & 0.12 & 0.07 & 0.32 & 0.26 & 0.35 \\
\hline TDS & & & 1.00 & -0.11 & 0.13 & 0.11 & -0.32 & -0.14 & -0.12 & -0.20 & 0.22 & 0.32 & -0.27 & -0.27 & -0.36 & -0.33 \\
\hline Cond & & & & 1.00 & 0.09 & 0.29 & -0.46 & -0.45 & 0.16 & -0.07 & 0.47 & 0.37 & -0.27 & 0.14 & 0.19 & 0.38 \\
\hline DO & & & & & 1.00 & 0.44 & 0.25 & 0.19 & -0.19 & 0.18 & -0.23 & -0.3 & -0.31 & -0.35 & -0.33 & -0.09 \\
\hline pH & & & & & & 1.00 & -0.31 & -0.19 & -0.04 & 0.21 & -0.01 & -0.07 & -0.18 & 0.25 & -0.20 & 0.04 \\
\hline Turb & & & & & & & 1.00 & 0.8 & -0.32 & -0.05 & -0.20 & -0.12 & -0.12 & -0.21 & 0.23 & 0.14 \\
\hline SS & & & & & & & & 1.00 & -0.45 & 0.11 & -0.34 & -0.33 & 0.10 & -0.33 & -0.22 & -0.42 \\
\hline BOD & & & & & & & & & 1.00 & 0.30 & 0.28 & 0.29 & 0.10 & 0.31 & 0.21 & 0.11 \\
\hline COD & & & & & & & & & & 1.00 & -0.16 & -0.19 & 0.01 & 0.13 & 0.25 & 0.13 \\
\hline Chla & & & & & & & & & & & 1.00 & 0.56 & -0.11 & 0.17 & 0.20 & 0.13 \\
\hline PT & & & & & & & & & & & & 1.00 & -0.03 & 0.37 & 0.57 & 0.33 \\
\hline $\mathbf{O}-\mathbf{P}$ & & & & & & & & & & & & & 1.00 & 0.40 & 0.01 & 0.0001 \\
\hline $\mathrm{NO}_{2}^{-}$ & & & & & & & & & & & & & & 1.00 & 0.30 & 0.4 \\
\hline $\mathrm{NO}_{3}^{2-}$ & & & & & & & & & & & & & & & 1.00 & 0.14 \\
\hline $\mathrm{NH}_{4}^{+}$ & & & & & & & & & & & & & & & & 1.00 \\
\hline
\end{tabular}

The turbidity allowing to assess the amount of suspended solids in water, the high values recorded in the lake in June and September would then be due to sediment transported by Ouémé River and Totchè Channel, and resuspension of particles deposited at the bottom by strong agitation of the water caused by the wind of these periods.

According to the classification of the Francophone Network on Water and Sanitation (REFEA), the lake with an average of 16 NTU, is considered slightly cloudy because between 5 and 30 NTU.

High concentrations of suspended solids observed during the flood period are related to terrestrial inputs of Sô river, Ouémé stream and Totchè channel.

The suspended solids can asphyxiate Some Aquatic Species-even and the whole aquatic environment when they are present in excess, or to cause momentary anoxia. According to the [20], there are risks of long-term chronic effects fatal for the aquatic life protection if the values exceed $5 \mathrm{mg} / \mathrm{L}$. This is the case of Nokoué lake whose average value is around $26.20 \mathrm{mg} / \mathrm{L}$.

The BOD has relatively high values, hovering around $14.5 \mathrm{mg} / \mathrm{L}$. The highest values observed in February and April are probably related to the decomposition of macrophytes in the lake. Thus, the high grades obtained in S2 is due to strong sewage discharges of Abomey-calavi directly into the water. As against those observed in S13 and S15 would be related to the decomposition of "acadjas" in the lake.

The mean values of BOD and COD are respectively $14.5 \mathrm{mg} / \mathrm{L}$ and $109.8 \mathrm{mg} / \mathrm{L}$. These values between 10 $\mathrm{mg} / \mathrm{L}$ and $25 \mathrm{mg} / \mathrm{L}$ for BOD and above $80 \mathrm{mg} / \mathrm{L}$ allow us to classify the water as bad quality [19].

The highest values of BOD obtained at S4, S5 and S6 stations can be justified by the impact of Dantokpa market (the biggest market in Benin) in the area, characterized by the dumping of all kinds of waste without any treatment.

The rate COD/BOD equal to 7.6, indicate an inorganic and toxic pollution, characterized by difficulty biodegradable substances which requires pretreatment.

Heavy organic pollutants values in nitrogen and phosphate elements observed in February and April (Great rainy season) are due to contributions from tributaries (Sô, Ouémé and Djonou). This pollution does not affect plants such as hygrophyte aquatic fish species [21]. 
The highest orthophosphate and total phosphorus values observed in S8 and S10, confirm external sources of phosphate fertilizer from Tchonvi and Kétonou, and drained by Ouémé river coming from the north of Benin. As against the low rated values of orthophosphate in S13 and S9 during the month of June show that this element is used by plants for their activity. High concentrations of February (dry season) could be from a release of phosphorus from lake sediments

Phosphorus contents of $3.45 \mathrm{mg} / \mathrm{Lon}$ average are much higher than those of the most natural waters where in the contents range between 0.05 and $0.02 \mathrm{mg} / \mathrm{L}$ [22].

It is also below the European standard set of toxicity at $6.1 \mathrm{mg} / \mathrm{L}$. Indeed, the problems of eutrophication in the waters start at the security levels of 0.34 to $0.70 \mathrm{mg} / \mathrm{L}$.

Ammonium concentrations are relatively low $(0.02 \mathrm{mg} / \mathrm{L}$ to $2,3 \mathrm{mg} / \mathrm{L})$ for all stations. There is therefore less risk to aquatic life. According to [17], a stream having a lower concentration to $44 \mathrm{mg} / \mathrm{L}$ can be considered as good.

Nitrate concentrations vary between 0.1 and $5.5 \mathrm{mg} / \mathrm{L}$ with a mean value of $0.9 \mathrm{mg} / \mathrm{L}$. These levels are all above $1 \mathrm{mg} / \mathrm{L}$ in April (beginning of the rainy season). Thus, based on the method of analysis of the Federal Office for Environment (FOEN), we can conclude that the high nitrate concentrations ( $>1.0 \mathrm{mg} / \mathrm{L})$ testify the intensive farming of the surrounding land, from inadequate fertilizer application or a high proportion of waste water.

Nitrite content at S6, S10, S18 and S19 sites exceeding the threshold value of $0.06 \mathrm{mg} / \mathrm{L}$ can hinder the development of aquatic fauna because of his toxicity [23].

The water quality assessment grid of OCDE allow to classify the lake Nokoué in the range of hyper-eutrophic waters (mean rate of chlorophyll a higher than $25 \mu \mathrm{g} / \mathrm{L}$ and mean rate of total phosphorus higher than 100 $\mathrm{mg} / \mathrm{m}^{3}$ ) characterized by the proliferation of aquatic plants. This has resulted in lack of oxygenation of the aquatic environment [3] causing asphyxiation of fish species and an imbalance in the food chain.

Table 2 shows the Correlation Matrix performed on all the data collected and indicate strong correlation (superior to 0.5 between salinity (sal) and conductivity (cond), temperature $\left(\mathrm{T}^{\circ} \mathrm{C}\right.$ ) and SS, turbidity and SS, total phosphorus (PT) and chlorophylla (chl.a),total phosphorus(PT) and Kjeldahlnitrogen, ammonium( $\left.\mathbf{N H}_{4}{ }^{+}\right)$and Kjeldahlnitrogen.

\section{Conclusions}

This monitoring study of Lake Nokoué pollution parameters allowed us to assess the level of pollution in the lake due to inflows of tributaries and various activities that lead to it. It shows that the quality of the lake has deteriorated causing eutrophication, with many consequences on aquatic life. It is therefore appropriate to give better attention to this important body of water for the well-being of the population. For this it is necessary to do regular and permanent physical-chemical parameters monitoring in the lake, but also to take action in line of limiting the diffusion of phosphorus, nitrogen, organic matter or pollutants, in the water or upstream. This requires:

- The sensitization of people who live on the lake and surrounding area to have an respectful and responsible behaviors of environment;

- A good knowledge of the watershed, necessary for the identification of various sources of pollution;

- The regulation of fishing techniques characterized by high intake of organic matter in the lake and therefore its siltation;

- Protection of riparian vegetation surrounding the lake and the rivers through the definition of a security perimeter, where any activity is forbidden.

\section{Acknowledgements}

The present study was carried out thanks to the support of the IFS (International Foundation for Science). We thank the officials of the foundation for everything they do for scientific research.

\section{References}

[1] Carlini, M. (2006) Morphologie et hydrodynamique des plans d'eau: Le cas des étangs-lacs en Limousin. Thèse de Doctorat, Université de Limoge, Limoge, 362 p.

[2] Trolle, D., Hamilton, D.P., Pilditch, C.A., Duggan, I.C. and Jeppesen, E. (2010) Predicting the Effects of Climate Change on Trophic Status of Three Morphologically Varying Lakes: Implications for Lake: Restoration and Management. Environmental Modelling \& Software, 26, 354-370. http://dx.doi.org/10.1016/j.envsoft.2010.08.009 
[3] Mama, D. (2010) Méthodologie et résultats du diagnostic de l’eutrophisation du lac Nokoué (Bénin). Mémoire de Thèse de l’Université de Lausanne, Lausanne, 157 p.

[4] Dehotin, U.A., Laleye, P.A., Dauta, A. and Moreau, J. (2007) Facteurs ecologiques et diversité piscicole d’une lagune Ouest Africaine: Le lac Nokoué au Bénin. Journal of Afrotropical Zoology, Special Issue, 49-55.

[5] Gnohossou, P.M. (2006) La faune benthique d'une lagune ouest africaine (le lac nokoue au benin), diversite, abondance, variations temporelles et spatiales, place dans la chaine trophique. Thèse de Doctorat, Institut National Polytechnique de Toulouse, Toulouse, $184 \mathrm{p}$.

[6] Dèdjiho, C.A. (2011) Évaluation de la chaine trophique d’une aire marine protégée en relation avec sa physico-chimie: Cas de Gbèzoumè dans la commune de Ouidah. Mémoire de DEA. FAST/UAC, Bénin.

[7] Pouomogne, V. (1998) Pisciculture en Milieu Tropical Africain. Comment produire du poisson à coût modéré. Presse Universitaire d’Afrique, Yaoundé, 263 p.

[8] Isabelle, M. (1999) Infiltration des eaux de ruissellement pluvial et transfert de polluants associés dans le sol urbain Vers une approche globale et pluridisciplinaire. Thèse de Doctorat, Institut National des Sciences Appliquées de Lyon, Lyon, p. 207.

[9] Abulude, F.O., Fapohunda, O.O. and Awanlenhen, B.E. (2006) Determination of Some Heavy Metals in Procambaris clakii, Paleanon sp., Macrobrahium vollenhovenii and Penaeus notalis from the Coastal Water of Ondo State, Nigeria. Journal of Animal and Veterinary Advances, 5, 38-41.

[10] Bawa, L.M., Djaneye-Boundjou, G., Boyode, B.P. and Assih, B.T. (2007) Water Quality Evaluation from Lomé’s Lagoon: Effects on Heavy Metals Contamination on Fishes. Journal of Applied Science and Environmental Management, 11, 33-36.

[11] Kanangire, C.K. (2001) Effet de l'alimentaire des poisons avec Azolla sur l'écosystème agro-piscicole au Rwanda. Dissertation présentée en vue de l’obtention du grade de Docteur en sciences.Faculté Universitaire Notre Dame de la Paix. Faculté des sciences, Namur-Belgique, 220 p.

[12] Zongo, F. (1993) Contribution a l'étude du phytoplancton d'eau douce du Burkina Faso- Cas du barrage $n^{\circ} 3$ de Ouagadougou. Thèse 3ème cycle, Univ. de Ouagadougou, Ouagadougou, 170 p.

[13] Lacroix, G. (1991) Lacs et rivières, milieux vivants, Éco guides Bordas, Paris.

[14] Guenda, W. (1996) Étude faunistique, écologique et de la distribution des insectes d’un réseau hydrographique de l'Ouest africain : le Mouhoun (Burkina Faso); rapport avec Simulium damnosum Theobald, vecteur de l'onchocercose. Thèse d'État, Université de droit, d'économie et des sciences d'Aix Marseille III, 13-50.

[15] Lamizana-Diallo, M B, Millogo-Rasolodimby, J. and Kenfack, S. (2008) Évaluation de la qualité physicochimique de l'eau d'un cours d'eau temporaire du Burkina Faso_-Le cas du Massili dans le Kadiogo. Sud Sciences et technologie.

[16] Wilson, J.R., Holst, N. and Rees, M. (2005) Determinants and Patterns of Population Growth in Water Hyacinth. Aquatic Botany, 81, 51-56. http://dx.doi.org/10.1016/j.aquabot.2004.11.002

[17] Beaux, J.F. (1998) L’environnement repères pratiques. Nathan, 64-71.

[18] Francis-Floyd, R. (2003) Dissolved Oxygen for Fish Production. Institute of Food and Agriculture Sciences, University of Florida, 3 p.

[19] MEDD \& Agences de l'eau (2003) Systèmed'évaluation de la qualité de l'eau des coursd'eau. Grilles d'évaluation SEQ- Eau (Version 2), 40 p.

[20] Ministère du Développement durable, Environnement et Parcs du Québec (MDDEP) (2007) Critères de qualité de l'eau de surface au Québec. http://www.mddep.gouv.qc.ca/eau/criteres_eau/index.htm

[21] Lamizana-Diallo, M.B. (2005) Effet du régime de la crue naturelle fluviale sur les hygrophytes. Cas d'un bief du Massili- Burkina Faso. Mémoire de DEA. Laboratoire de biologie et d'écologie végétales. UFR-SVT, Université de Ouagadougou, Ouagadougou, $77 \mathrm{p}$.

[22] Chapman, D. and Kimstach, V. (1996) Selection of Water Quality Variables. Water Quality Assessments: A Guide to the Use of Biota, Sediments and Water in Environment Monitoring, Chapman Edition, 2nd Edition, E and FN Spon, London, 59-126. http://dx.doi.org/10.4324/noe0419216001.ch3

[23] André, G. (1995) Ecolochimie. Paris, 351 p. 